\title{
PENGARUH DISIPLIN DAN KOMUNIKASI TERHADAP KINERJA DOSEN DENGAN KEPEMIMPINAN SEBAGAI VARIABEL MODERASI PADA STIE SULTAN AGUNG PEMATANGSIANTAR
}

\author{
Oleh: \\ Erbin Chandra \\ Dosen STIE Sultan Agung Pematangsiantar
}

Abstraksi

Sampel pada penelitian ini adalah semua dosen pada STIE Sultan Agung Pematangsiantar yang berjumlah 45 Orang. Data dalam penelitian ini adalah data primer. Data dikumpulkan dengan menggunakan kuesioner yang dibagikan langsung kepada responden. Metode analisa yang digunakan adalah model Regresi Linear Berganda. Untuk menguji hipotesis secara simultan digunakan Uji F dan secara parsial digunakan Uji t.

Hasil dari pengujian yang dilakukan dengan SPSS diperoleh persamaan regresi berganda : $Y=\mathbf{1 0 , 5 3 9 +}$ $\mathbf{0 , 3 9 7} \mathbf{X}_{1}+\mathbf{0 , 4 5 3} \mathbf{X}_{2}$. Yang berarti nilai konstanta sebesar 10,539 yang menunjukkan bahwa apabila variabel disiplin dan komunikasi diasumsikan bernilai nol, maka nilai dari kinerja dosen adalah sebesar 10,539. Jika variabel bebas meningkat $1 \%$ maka kinerja dosen akan meningkat.

Hasil hipotesa uji $t$ hitung variabel penelitian adalah variabel disiplin diperoleh $t_{\text {hitung }} 4,166$ dengan probabilitas signifikan 0,000 lebih kecil dari tingkat keyakinan (level of significant) $\alpha=0,05$, untuk komunikasi diperoleh $\mathrm{t}_{\text {hitung }} 3,635$ dengan probabilitas signifikan 0,001 lebih kecil dari tingkat keyakinan (level of significant) $\alpha=0,05$. Maka keputusan yang diambil adalah menolak Ho dan menerima Ha, artinya secara parsial disiplin dan komunikasi berpengaruh signifikan terhadap kinerja dosen STIE Sultan Agung Pematangsiantar

Hasil dari pengujian yang dilakukan dengan moderating diperoleh persamaan regresi berganda : $\mathbf{Y}=$ $63,632+1,266 \mathrm{ZX}_{1}+1,581 \mathrm{ZX}_{2}+2,189 \mathrm{ZX}_{3}+1,747 \mathrm{Abs}_{1} \mathrm{X}_{3}+1,373 \mathrm{Abs}_{2} \mathrm{X}_{3}+$ e. Uji hipotesis menunjukkan bahwa kelima variabel berpengaruh positif terhadap kinerja dosen. Untuk kedua variabel moderating diperoleh $t_{\text {hitung }} 2,064$ dan $t_{\text {hitung }} 1,735$ dengan probabilitas signifikan 0,046 dan 0,091 dari tingkat keyakinan (level of significant) $\alpha=0,05$. Hasil penelitian ini menunjukkan bahwa variabel kepemimpinan mampu memoderasi variabel kedisiplinan namun tidak memoderasi variabel komunikasi.

Kata Kunci : Disiplin, Komunikasi, Kepemimpinan, Kinerja Dosen dan Moderasi

Abstraction

The sample of this research was all lecture in STIE Sultan Agung Pematangsiantar whose numbers were 45 peoples. Research data were primary data. Data were collected by using questionnaires which were distributed directly to the respondents. Analyzing method used was double linear regression model. Hypothesis was tested simultaneously by using $F$ test and partially by using $t$ test.

The result of the test were performed by the SPSS obtained the multiple regression equation: $\boldsymbol{Y}=$ $10,539+0,397 X_{1}+\mathbf{0 , 4 5 3} X_{2}$. Which means the constant's value of 10,539 which shows that if the variable of discipline and communication is assumed zero, then the value of the lecturer performance is equal to 10,539. If independent variables increase by $1 \%$, then lecturer performance will also increase.

The result of the hypothesis testing $t_{\text {count }}$ study variable is variable's disicipline obtained $t_{\text {count }} 4,166$ with significant probability 0,000 is smaller than level of significant $\alpha=0,05$, for communication obtained $t_{\text {count }} 3,635$ with significant probabillity 0,001 is smaller than level of significant $a=0,05$. So the decision is rejecting Ho and accepting $\mathrm{Ha}$, it means, partially variable disicipline and communication significant influent on lecturer performance on STIE Sultan Agung Pematangsiantar.

The result of the test were performed by moderating obtained the multiple regression equation : $\boldsymbol{Y}=$ $63,632+1,266 \mathrm{ZX}_{1}+1,581 \mathrm{ZX}_{2}+2,189 \mathrm{ZX}_{3}+1,747 \mathrm{Abs}_{1-} \mathrm{X}_{3}+1,373 \mathrm{Abs}_{2} \mathrm{X}_{3}+e$. The hypotesis which shows that all five variables give positive influent on lecturer performance. For the moderating variables obtained $t_{\text {count }} 2,064$ and $t_{\text {count }}$ 1,735 with significant probabillity 0,046 and 0,091 from level of significant $a=$ 0,05. The result of this research shows that leadership variable can moderating the discipline variable but it can't moderating communication variable.

Keywords : Discipline, Communication, Leadership, Lecturer Performance and Moderating

\section{A. PENDAHUluAN}

1. Latar Belakang Masalah

Dewasa ini, tanpa sumber daya manusia yang berkualitas, suatu organisasi tidak akan mampu bertahan dalam persaingan yang begitu ketat. Maka setiap organisasi pada saat ini tertuntut untuk mampu meningkatkan kualitas dan kinerja para anggotanya.
STIE Sultan Agung Pematangsiantar merupakan salah satu perguruan tinggi yang terdapat di kota Pematangsiantar. Sama halnya dengan perguruan tinggi lainnya, STIE Sultan Agung juga memiliki perhatian khusus terhadap para dosen menyangkut kinerja mereka. Karena untuk mampu bersaing di dalam kompetisi sesama perguruan tinggi, dosen merupakan modal utama yang penting. 
Dosen yang berkualitas dan berkinerja baik tentunya mampu menciptakan lulusan-lulusan yang berkualitas pula sehingga mampu meningkatkan citra dan kualitas dari perguruan tinggi tersebut.

Kedisiplinan merupakan salah satu faktor dalam meningkatkan kinerja dosen. Disiplin merupakan perasaan taat dan patuh terhadap nilainilai yang dipercaya termasuk melakukan pekerjaan tertentu yang menjadi tanggung jawabnya. STIE Sultan Agung juga selalu berupaya agar para dosendosennya mampu selalu berdisiplin. Namun, kenyataannya kedisiplinan para dosen pada STIE Sultan Agung masih belum dapat dikatakan baik yang tentunya hal ini juga menyebabkan kinerja mereka menjadi kurang baik. Hal ini terbukti dalam beberapa hal. Masalah utama dalam hal kedisiplinan pada STIE Sultan Agung adalah disiplin waktu. Setiap dosen semestinya telah mengetahui dengan jelas jam masuk untuk mengajar. Tetapi masih banyak kejadian berupa telatnya dosen pada STIE Sultan Agung dalam memberikan perkuliahan. Masalah waktu tersebut juga terjadi pada selesainya perkuliahan. Masalah-masalah pelanggaran kedisiplinan inilah yang sangat nyata terjadi pada STIE Sultan Agung yang mendorong penulis untuk menjadikan variabel disiplin sebagai salah satu variabel dalam penelitian ini.

Selain kedisiplinan, komunikasi juga merupakan salah satu faktor yang mempengaruhi kinerja. STIE Sultan Agung Pematangsiantar dalam menjalankan aktivitasnya sehari-hari juga tidak terlepas dari komunikasi. Komunikasi yang dilakukan secara intensif, baik, dan lancar dengan hasil tersampainya informasi dengan jelas tentunya dapat memicu peningkatan kinerja seseorang khususnya para dosen di perguruan tinggi. Komunikasi pada STIE Sultan Agung Pematangsiantar dapat dikatakan cukup baik. Namun masih terdapat banyak hal yang perlu dievaluasi terkait masalah komunikasi pada STIE Sultan Agung. Dalam banyak kasus, penyampaian informasi mengenai pekerjaan, kegiatan, acara dan lain sebagainya pada STIE Sultan Agung masih belum dapat tersampaikan dengan baik. Untuk itu komunikasi pada STIE Sultan Agung merupakan variabel berikutnya yang dipilih oleh penulis dalam penelitian ini.

Kepemimpinan merupakan salah satu faktor yang dapat meningkatkan kinerja dosen. Dapat dikatakan bahwa pemimpinlah yang berperan paling penting dan paling berpengaruh terhadap tingkat kedisiplinan dan komunikasi dalam sebuah organisasi yang sama halnya juga pada STIE Sultan Agung Pematangsiantar. Jika pemimpin STIE Sultan Agung mampu berupaya untuk meningkatkan kedisiplinan dan komunikasi, tentunya kinerja dosen akan semakin ditingkatkan. Berdasarkan alasan ini maka penulis menjadikan kepemimpinan sebagai variabel moderasi dalam penelitian ini.

\section{Rumusan Masalah}

a. Apakah disiplin berpengaruh positif dan signifikan terhadap kinerja dosen di STIE Sultan Agung Pematangsiantar ?

b. Apakah komunikasi berpengaruh positif dan signifikan terhadap kinerja dosen di STIE Sultan Agung Pematangsiantar?

c. Apakah kepemimpinan memoderisasi hubungan antara disiplin dan komunikasi terhadap kinerja dosen di STIE Sultan Agung Pematangsiantar?

\section{Tujuan Penelitian}

a. Untuk mengetahui pengaruh disiplin terhadap kinerja dosen di STIE Sultan Agung Pematangsiantar.

b. Untuk mengetahui pengaruh komunikasi terhadap kinerja dosen di STIE Sultan Agung Pematangsiantar.

c. Untuk mengetahui apakah kepemimpinan memoderisasi hubungan antara disiplin dan komunikasi terhadap kinerja dosen di STIE Sultan Agung Pematangsiantar.

\section{Metode Penelitian}

Lokasi atau tempat penelitian ini dilakukan di Sekolah Tinggi Ilmu Ekonomi Sultan Agung Jl. Surabaya No. 19 Pematangsiantar. Pada penelitian ini yang menjadi populasi adalah seluruh dosen sebanyak 45 orang $(\mathrm{N}=45)$ yang akan menjadi populasi sekaligus menjadi sampel untuk menjawab kuesioner yang dijalankan penulis. Oleh karena subjek yang ada kurang dari 100, maka penelitian ini adalah penelitian populasi sampel jenuh dimana subjek yang ada diteliti.

Adapun Desain penelitian yang digunakan dalam penulisan tesis ini adalah Penelitian Kepustakaan (Library Research) dan Penelitian Lapangan (Field Research). Teknik pengumpulan data yang dilakukan penulis dalam penelitian ini adalah berupa Kuesioner, Wawancara, Dokumentasi dan Observasi. Adapun jenis data yang digunakan dalam penelitian ini adalah jenis data kualitatif dan data kuantitatif. Hasil data yang diperoleh dari lapangan akan dianalisis secara deskriptif baik bersifat kualitatif dan kuantitatif.

\section{B. LANDASAN TEORI}

\section{Manajemen Sumber Daya Manusia}

Menurut Dessler (2006:5), manajemen sumber daya manusia adalah proses memperoleh, melatih, menilai dan memberikan kompensasi kepada karyawan dengan memperhatikan hubungan kerja, kesehatan, keamanan dan keadilan. Sedangkan menurut Simamora (2004:4), manajemen sumber daya manusia adalah pendayagunaan, pengembangan, penilaian, pemberian balas jasa dan pengorbanan individu anggota organisasi atau kelompok karyawan. Menurut uraian para ahli di atas, maka dapat diambil kesimpulan bahwa manajemen sumber daya manusia adalah suatu seni dalam mengelola orang-orang yang terdapat dalam suatu organisasi agar mereka dapat bekerja sebaik 
mungkin demi mencapai tujuan perusahaan dan juga tujuan pribadi mereka.

Menurut Mondy (2008:5) manajemen sumber daya manusia memiliki lima fungsi yaitu antara lain:

a. Penyediaan staf

Merupakan proses yang dilakukan perusahaan untuk selalu memiliki dan menjamin ketersediaan karyawan yang tepat dengan kemampuannya, yang memadai dalam pekerjaannya serta tepat waktu penggunaannya.

b. Pengembangan sumber daya manusia Kegiatan manajemen juga meliputi kegiatan pengembangan dan pelatihan didalamnya.

c. Kompensasi

Pemberian kompensasi yang terencana, matang, layak dan adil sesuai dengan kontribusi karyawan dalam perusahaan.

d. Kesehatan dan keselamatan

Penciptaan istilah tempat kerja yang aman dan pekerjaan yang aman atau kondisi yang sehat dan aman sehubungan dengan kerja.

e. Hubungan Karyawan

Motivasi karyawan dalam hubungan kepegawaian yang baik untuk menciptakan suasana yang baik pula.

\section{Disiplin}

Menurut Siagian (2003:305), kedisiplinan adalah tindakan manajemen untuk mendorong para anggota organisasi memenuhi tuntutan berbagai ketentuan atau suatu bentuk pelatihan yang berusaha memperbaiki dan membentuk pengetahuan, sikap dan perilaku karyawan sehingga para karyawan tersebut secara sukarela bekerja secara kooperatif. Menurut Siswanto (2005:4), disiplin adalah suatu sikap menghormati, menghargai, patuh dan taat pada peraturan-peraturan yang berlaku baik yang tertulis maupun yang tidak tertulis serta sanggup menjalankannya dan tidak mengelak menerima sanksi-sanksi apabila ia melanggar tugas dan wewenang yang diberikan. Dari definisi di atas maka penulis mengambil kesimpulan bahwa disiplin merupakan suatu peraturan-peraturan yang ditetapkan oleh suatu organisasi yang bersifat relatif dan bertujuan sebagai suatu alat pengendali agar para tenaga kerja mereka mampu bekerja tanpa melewati batasan-batasan yang telah ditetapkan.

Menurut Tulus (2004:33) ada beberapa indikator sikap disiplin yang dilakukan dalam pekerjaan, yaitu :

a. Disiplin terhadap peraturan, yaitu tatanan dan sikap taat pada norma-norma.

b. Disiplin terhadap diri, yaitu suatu sikap kesadaran dan perilaku diri.

c. Disiplin terhadap kualitas, yaitu pemenuhan kualitas kerja.

d. Disiplin terhadap prioritas kerja, yaitu sasaran utama dalam bekerja.

e. Disiplin terhadap prosedur, yaitu penggunaan cara dan proses dalam bekerja.

\section{Kepemimpinan}

Robbins dan Timothy (2009:49) mendefinisikan kepemimpinan sebagai kemampuan untuk memengaruhi suatu kelompok guna mencapai sebuah visi atau serangkaian tujuan yang ditetapkan. Sedangkan Griffin (2002:68) menjelaskan bahwa kepemimpinan adalah penggunaan pengaruh tanpa paksaan untuk membentuk tujuan-tujuan grup atau organisasi, memotivasi perilaku ke arah pencapaian tujuan-tujuan tersebut, dan membantu mendefinisikan kultur grup atau organisasi. Berdasarkan pendapat para ahli di atas, penulis menyimpulkan bahwa kepemimpinan adalah suatu seni atau keahlian dalam menjalin hubungan dan memengaruhi orang-orang dalam suatu organisasi agar mereka dapat berkinerja sebaik mungkin untuk mencapai tujuan organisasi.

Menurut Mintzberg dalam Griffin (2002:17), peran-peran kepemimpinan meliputi: peran interpersonal, peran informasional, dan peran pengambilan keputusan.

\section{Kinerja}

Mangkunegara (2001:67) mengemukakan bahwa kinerja (prestasi kerja) adalah hasil kerja secara kualitas dan kuantitas yang dicapai oleh seseorang pegawai dalam melaksanakan tugasnya sesuai dengan tanggung jawab yang diberikan kepadanya. Menurut Rivai (2004:309), kinerja merupakan perilaku yang nyata yang ditampilkan setiap orang sebagai prestasi kerja yang dihasilkan oleh karyawan sesuai dengan perannya dalam perusahaan. Berdasarkan beberapa definisi diatas maka dapat diambil kesimpulan bahwa kinerja karyawan adalah hasil atau output dari pengorbanan tenaga, waktu, pikiran seseorang demi organisasi yang menunjukkan sifat berkompetensi dan merupakan kunci keberhasilan dalam menjalankan tugas dan tanggung jawab dengan keinginan berupa umpan balik yang jelas.

Berkaitan dengan kinerja dosen, ditetapkan dalam Peraturan Pemerintah Pendidikan dan Kebudayaan Nomor 154 Tahun 2014 tentang Jabatan Fungsional Dosen dan Angka Kreditnya. Dalam Kepmen tersebut dinyatakan bahwa tugas pokok dosen adalah melaksanakan pendidikan dan pengajaran pada perguruan tinggi, penelitian serta pengabdian kepada masyarakat.

\section{PEMBahasan}

\section{Analisa}

\section{a. Analisa Deskriptif Kualitatif}

Analisa deskriptif kualitatif adalah merupakan suatu analisa yang digunakan untuk mendapatkan suatu gambaran dan deskripsi tentang tanggapan responden mengenai pengaruh disiplin dan komunikasi terhadap kinerja dosen dengan kepemimpinan sebagai variabel moderasi pada STIE Sultan Agung Pematangsiantar. Setelah melakukan pengujian data, maka selanjutnya penulis akan melanjutkan untuk melakukan analisa kualitatif sebagai gambaran dari objek dan variabel penelitian yang bersangkutan. Adapun penetapan kriteria nilai 
rata-rata jawaban dari responden tersebut dimasukkan dalam kelas-kelas interval dimana penentuan intervalnya memakai rumus sebagai berikut:

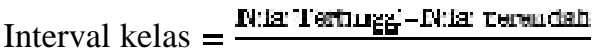

Kriteria:

Nilai terbaik $=5$

Nilai terendah $=1$

Jumlah kelas $=5$

Dari rumus diatas diperoleh interval kelas = 0,8 sehingga berlaku ketentuan kategori hasil sebagai berikut:

Tabel 1

Nilai Interval dan Kategori Jawaban Responden

\begin{tabular}{|c|c|}
\hline Nilai Interval & Kategori \\
\hline $1,00-1,80$ & Sangat Tidak Baik (STB) \\
\hline $1,81-2,60$ & Tidak Baik (TB) \\
\hline $2,61-3,40$ & Cukup Baik (CB) \\
\hline $3,41-4,20$ & Baik (B) \\
\hline $4,21-5,00$ & Sangat Baik (SB) \\
\hline
\end{tabular}

Sumber: hasil pengolahan data

\section{b. Analisa Deskriptif Kuantitatif}

1) Analisa Regresi Linear Berganda

\section{a) Analisa Regresi Linear Berganda 1}

Teknik analisa data yang digunakan dalam penelitian ini adalah analisa statistik regresi linier berganda dengan menggunakan program SPSS 20 Analisis regresi digunakan untuk memprediksi pengaruh variabel bebas terhadap variabel terikat.

Teknik analisa statistik regresi linear berganda dengan menggunakan program SPSS 20. Hasi analisa regresi berganda digunakan untuk melihat pengaruh dari variabel independent / bebas terhadap variabel dependent / terikat dapat dilihat pada tabel di bawah ini.

Tabel 2

Tabel Regresi Linier Berganda

\begin{tabular}{|c|c|c|c|c|c|c|c|c|}
\hline \multirow[t]{2}{*}{ Nod } & & \multicolumn{2}{|c|}{$\begin{array}{l}\text { Unitontarbiass } \\
\text { Costifcents }\end{array}$} & \multirow{2}{*}{$\begin{array}{c}\text { Sandardias } \\
d \\
\text { Cartocents } \\
\text { Bets }\end{array}$} & \multirow[t]{2}{*}{$t$} & \multirow[t]{2}{*}{$\mathrm{Sig}}$. & \multicolumn{2}{|c|}{$\begin{array}{l}\text { Coilnesity } \\
\text { Sintates }\end{array}$} \\
\hline & & $\theta$ & Stet Eroe & & & & Toieanc & ve. \\
\hline \multirow{3}{*}{1} & Constart] & 10559 & 7638 & & 1390 & 175 & & \\
\hline & Dispen & 399 & $\cos 6$ & 473 & 4166 & $\infty \infty 0$ & 396 & $12 \pi$ \\
\hline & Konunika & 453 & 125 & 413 & 3.635 & $\infty$ & 786 & 1272 \\
\hline
\end{tabular}

a. Dependent Variable: Kinerja_Dosen Sumber : Data Primer diolah 2016, SPSS

Dari hasil analisa dengan program SPSS pada Tabel 4.9 di atas dapat dilihat model regresi yang dihasilkan sebagai berikut :

$$
Y=10,539+0,397 X_{1}+\mathbf{0 , 4 5 3} X_{2}
$$

Dari model persamaan regresi berganda yang diperoleh di atas dapat diartikan bahwa variabel bebas yakni disiplin dan motivasi menunjukkan hubungan yang searah atau positif terhadap kinerja dosen, dimana setiap kenaikan variabel independen ini akan menyebabkan naiknya kinerja dosen dan sebaliknya jika terjadi penurunan pada disiplin dan komunikasi maka akan menyebabkan kinerja dosen menurun.

Untuk melihat seberapa besar variasi kinerja dosen dapat dijelaskan oleh variasi disiplin dan komunikasi dapat diketahui dari perhitungan Koefisien Determinasi $\left(\mathrm{R}^{2}\right)$ yang ditunjukkan Tabel 4.10. Perhitungan koefisien determinasi menunjukkan bahwa nilai $\mathrm{R}$ Square sebesar 0,575 yang berarti variasi disiplin dan komunikasi dapat menjelaskan variasi dari kinerja dosen pada STIE Sultan Agung Pematangsiantar sebesar 0,575 $(57,5 \%)$ dan sisanya sebesar $42,5 \%$ dapat dijelaskan oleh faktor lain yang tidak dibahas dalam penelitian ini, seperti kompensasi, komitmen organisasi, budaya organisasi, dan faktor lainnya.

Tabel 3

Tabel Koefisien Determinasi

Model Summary

\begin{tabular}{|c|c|c|c|c|}
\hline & & IMOd & el summary & \\
\hline Maere & A & R Sccule & Adjusied R Sevare & $\begin{array}{l}\text { Sid. Eiror ef ohe } \\
\text { Estimats }\end{array}$ \\
\hline , & $.752^{\circ}-(x-3)$ & s75 & 554 & 3.702 \\
\hline
\end{tabular}

a. Predictors: (Constant), Komunikasi, Disiplin

b. Dependent Variable: Kinerja_Dosen

Sumber : Data Primer diolah 2016, SPSS

\section{b) Analisa Regresi Linear Berganda 2}

Teknik analisa statistik regresi linear berganda dengan menggunakan program SPSS 20. Hasil analisa regresi berjenjang digunakan untuk melihat pengaruh dari variabel moderating terhadap variabel bebas dan variabel terikat dapat dilihat pada Tabel 3 .

Tabel 4

Uji Signifikansi Parameter Individual Moderasi Coefficients $^{\mathrm{a}}$

\begin{tabular}{|c|c|c|c|c|c|c|}
\hline \multirow{2}{*}{\multicolumn{2}{|c|}{ Matel }} & \multicolumn{2}{|c|}{$\begin{array}{l}\text { Unsiandarosese } \\
\text { Coefficients }\end{array}$} & \multirow{2}{*}{$\begin{array}{c}\begin{array}{c}\text { Standaraboed } \\
\text { Coethoients }\end{array} \\
\text { Buts. }\end{array}$} & \multirow[t]{2}{*}{1} & \multirow[t]{2}{*}{ so } \\
\hline & & E & Sost Erat & & & \\
\hline \multirow{6}{*}{1} & (Censtara) & हु 832 & 1834 & & 78282 & $\Delta 00$ \\
\hline & Zseoredoping & 1.260 & .062 & $2 z$ & 1904 & .000 \\
\hline & Zstareikomureasio & 1.681 & 600 & 246 & 2697 & Dnt3 \\
\hline & Iscareikepenimpina & 2.60 & 321 & 966 & 2038 & .004 \\
\hline & Aes $x$ i & 1.747 & 847 & 12 & 2084 & ses \\
\hline & $\operatorname{ses} \times 2 \times 0$ & 1. & 791. & 181 & 1725 & .091 \\
\hline
\end{tabular}

a. Dependent Variable: Kinerja_Dosen

Sumber : Data Primer diolah 2016, SPSS

Berdasarkan hasil uji nilai selisih mutlak diperoleh persamaan regresi sebagai berikut:

$\mathrm{Y}=63,632+1,266 \mathrm{ZX}_{1}+1,581 \mathrm{ZX}_{2}+2,189 \mathrm{ZX}_{3}+$

$1,747 \mathrm{AbsX}_{1} \mathrm{X}_{3}+1,373 \mathrm{AbsX}_{2} \mathrm{X}_{3}+\mathrm{e}$

Dari hasil tampilan SPSS tabel Coefficients menunjukkan bahwa variabel Zdisiplin memberikan nilai koefisien 1,266 dengan probabilitas signifikan 0,06. Dari data tabel di atas dapat disimpulkan bahwa pada taraf signifikansi 5\%, diketahui disiplin berpengaruh positif tetapi tidak signifikan terhadap kinerja dosen. Variabel Zkomunikasi memberikan nilai koefisien 1,581 dengan probabilitas 0,013 menunjukkan bahwa komunikasi berpengaruh positif dan signifikan terhadap kinerja dosen. Variabel Zkepemimpinan memberikan nilai koefisien 2,189 dengan probabilitas 0,04 yang artinya bahwa 
kepemimpinan berpengaruh positif dan signifikan terhadap kinerja dosen. Variabel moderator juga dapat dilihat bahwa $\mathrm{Abs}_{1} \mathrm{X}_{3}$ signifikan (probabilitas 0,46 ) tetapi $\mathrm{Abs}_{2} \mathrm{X}_{3}$, ternyata tidak signifikan yaitu dengan probabilitas signifikan sebesar 0,91 atau dapat dikatakan bahwa variabel kepemimpinan mampu memoderasi variabel kedisiplinan namun tidak memoderasi variabel komunikasi.

Untuk melihat seberapa besar pengaruh variabel bebas terhadap variabel terikat dapat diketahui dari perhitungan Koefisien Determinasi $\left(\mathrm{R}^{2}\right)$ yang ditunjukkan Tabel 4 berikut dengan pengolahan SPSS 20 sebagai berikut :

Tabel 5

Tabel Koefisien Determinasi Moderasi Model Summary

\begin{tabular}{|l|r|r|r|r|}
\hline Modet & $R$ & R Square & \multicolumn{1}{c|}{$\begin{array}{c}\text { Adjusted } R \\
\text { Square }\end{array}$} & $\begin{array}{c}\text { Std Error of the } \\
\text { Estimate }\end{array}$ \\
\hline 1 & $.842^{2}$ & .709 & 672 & 3.175 \\
\hline
\end{tabular}

a. Predictors: (Constant), ABSX2_X3,

Zscore(Komunikasi),

ABSX1_X3, Zscore(Disiplin),

Zscore(Kepemimpinan)

Sumber : Data Primer diolah 2016, SPSS

Tampilan output SPSS diatas menunjukkan nilai $\mathrm{R}$ Square yang kuat atau sebesar 0,709 atau $70,9 \%$ yang berarti variasi kinerja dosen dapat dijelaskan oleh variasi Zdisiplin, Zkomunikasi, Zkepemimpinan dan Abs $\mathrm{X}_{1} \mathrm{X}_{3}$ Abs $\mathrm{X}_{2} \mathrm{X}_{3}$ sebesar $70,9 \%$ dan sisanya $29,1 \%$ dijelaskan oleh variabel lain diluar model ini.

\section{2) Pengujian Hipotesis}

a) Pengujian Hipotesis 1

\section{(1) Uji Signifikansi Parsial (Uji t)}

Dengan penggunaan program SPSS 20 pada Tabel 1 di atas, maka hasil uji t pada penelitian bahwa hasil pengujian variabel disiplin diperoleh $\mathrm{t}_{\text {hitung }}$ 4,166 dengan probabilitas signifikan 0,000 lebih kecil dari tingkat keyakinan (level of significant) $\alpha=0,05$. Maka keputusan yang diambil adalah menolak Ho dan menerima Ha. Artinya secara parsial disiplin berpengaruh positif dan signifikan terhadap kinerja dosen pada STIE Sultan Agung Pematangsiantar.

Hasil pengujian variabel komunikasi diperoleh $t_{\text {hitung }}$ 3,635 dengan probabilitas signifikan 0,001 lebih kecil dari tingkat keyakinan (level of significant) $\alpha=0,05$. Maka keputusan yang diambil adalah menolak Ho dan menerima $\mathrm{Ha}$, artinya secara parsial komunikasi berpengaruh positif dan signifikan terhadap kinerja dosen pada STIE Sultan Agung Pematangsiantar.

Dari kedua variabel bebas di atas, dapat dilihat bahwa variabel disiplin berpengaruh paling tinggi atau dominan $\left(\beta_{1}>\beta_{2}\right)$ terhadap kinerja dosen pada STIE Sultan Agung Pematangsiantar.

\section{(2) Uji F Statistik}

Dengan bantuan program SPSS, maka pada penelitian ini diperoleh nilai $\mathrm{F}_{\text {hitung }}$ sebesar 28,367 adalah lebih besar dari $\mathrm{F}_{\text {tabel }}$ untuk $\alpha=5 \%$ sebesar 3,30. Jadi dapat disimpulkan bahwa Ho ditolak dan Ha diterima, yang berarti bahwa ada pengaruh signifikan dari variabel bebas (disiplin dan komunikasi) terhadap variabel terikat (kinerja dosen) secara simultan. Hasil uji F pada penelitian ini dapat dilihat pada Tabel 5 berikut:

\section{Tabel 6}

Uji F Statistik

ANOVA $^{\text {a }}$

\begin{tabular}{|c|c|c|c|c|c|c|}
\hline 10002 & & Sim of Squares & of & Mean Sacore & $f$ & Sig. \\
\hline \multirow{3}{*}{1} & Regression & $m .600$ & 2 & 338.802 & 28.368 & $208^{\circ}$ \\
\hline & Residus: & 575645 & 42 & 19705 & & \\
\hline & Toial & 135324 & 44 & & & \\
\hline
\end{tabular}

a. Dependent Variable: Kinerja_Dosen

b. Predictors: (Constant), Komunikasi, Disiplin Sumber : Data Primer diolah 2016, SPSS

\section{b) Pengujian Hipotesis 2}

Dengan bantuan program SPSS, maka hasil uji $\mathrm{F}$ pada penelitian ini dapat dilihat pada Tabel 6 berikut:

Tabel 7

Uji F Statistik Moderasi ANOVA $^{\mathrm{a}}$

\begin{tabular}{|c|c|c|c|c|c|c|}
\hline Noces & & Sum ol squares & ef & Meer Szäare & $f$ & 59. \\
\hline \multirow{3}{*}{1} & Regressisn & 960.056 & 6 & $19201 \%$ & 19.048 & $500^{\circ}$ \\
\hline & Residur: & $383+48$ & 39 & 10081 & & \\
\hline & Tolal & 1351.24 & 44 & & & \\
\hline
\end{tabular}

Sumber : Data Primer diolah 2016, SPSS

b. Predictors: (Constant), ABSX2_X3,

Zscore(Komunikasi), ABSX1_X3, Zscore(Disiplin),

Zscore(Kepemimpinan)

a. Dependent Variable: Kinerja_Dosen

Dari tabel di atas menunjukkan bahwa nilai $\mathrm{F}$ hitung sebesar 19,048 dengan tingkat signifikansi 0,000 jauh dibawah 0,05 . Hal ini berarti bahwa variabel standardized disiplin, standardized komunikasi, standardized kepemimpinan dan $\mathrm{ABSX}_{1} \mathrm{X}_{3}, \mathrm{ABSX}_{2} \mathrm{X}_{3}$ secara bersama-sama atau simultan memengaruhi kinerja dosen.

\section{Pembahasan Hasil Penelitian}

a) Kinerja Dosen STIE Sultan Agung Pematangsiantar

Kinerja yaitu suatu kemajuan atau pencapaian hasil kerja dengan kriteria tertentu yang dilakukannya berdasarkan potensi yang dimilikinya dengan penilaian dari orang tertentu. Kinerja dosen ditetapkan dalam Peraturan Pemerintah Pendidikan dan Kebudayaan Nomor 154 Tahun 2014 tentang Jabatan Fungsional Dosen dan Angka Kreditnya. Dalam Kepmen tersebut dinyatakan bahwa tugas pokok dosen adalah melaksanakan pendidikan dan pengajaran pada perguruan tinggi, penelitian serta pengabdian kepada masyarakat. 
Kinerja dosen pada STIE Sultan Agung Pematangsiantar dapat dilihat dari berbagai faktor seperti yang terdapat dalam pertanyaan kuesioner. Adapun hasil yang diperoleh untuk kinerja dosen adalah sebanyak 0,4 dalam tingkatan tidak baik, $5,6 \%$ dalam tingkatan cukup baik, 50\% dalam tingkatan baik, serta $44 \%$ berkategori sangat baik.

\section{b) Disiplin STIE Sultan Agung Pematangsiantar}

Kinerja Disiplin adalah suatu peraturanperaturan yang ditetapkan oleh suatu organisasi yang bersifat relatif dan bertujuan sebagai suatu alat pengendali agar para tenaga kerja mereka mampu bekerja tanpa melewati batasan-batasan yang telah ditetapkan.

Disiplin pada STIE Sultan Agung Pematangsiantar dapat dilihat dari berbagai faktor seperti yang terdapat dalam pertanyaan kuesioner. Adapun hasil yang diperoleh untuk disiplin adalah sebanyak 0,4 dalam tingkatan tidak baik, 9,5\% dalam tingkatan cukup baik, 57,8\% dalam tingkatan baik, serta $32,3 \%$ berkategori sangat baik.

\section{c) Komunikasi STIE Sultan Agung \\ Pematangsiantar}

Komunikasi merupakan suatu kegiatan untuk menyampaikan pesan atau informasi dari suatu orang ke orang lain melalui sebuah proses baik secara lisan maupun tulisan sehingga penerima mampu menerima pesan atau informasi tersebut sesuai dengan maksud dari pengirim.

Komunikasi pada STIE Sultan Agung Pematangsiantar dapat dilihat dari berbagai faktor seperti yang terdapat dalam pertanyaan kuesioner. Adapun hasil yang diperoleh untuk komunikasi pada STIE Sultan Agung adalah sebanyak 0,6\% dalam tingkatan tidak baik, kategori cukup baik sebanyak $4,3 \%, 49,8 \%$ dalam tingkatan baik, serta $45,3 \%$ berkategori sangat baik.

\section{d) Kepemimpinan STIE Sultan Agung Pematangsiantar}

Kepemimpinan merupakan suatu seni atau keahlian dalam menjalin hubungan dan memengaruhi orang-orang dalam suatu organisasi agar mereka dapat berkinerja sebaik mungkin untuk mencapai tujuan organisasi.

Kepemimpinan ketua STIE Sultan Agung Pematangsiantar dapat dilihat dari berbagai faktor seperti yang terdapat dalam pertanyaan kuesioner. Adapun hasil yang diperoleh untuk kepemimpinan pada STIE Sultan Agung adalah sebanyak 4,6\% dalam tingkatan cukup baik, 55,6\% dalam tingkatan baik, serta $39,8 \%$ berkategori sangat baik.

\section{KESIMPULAN DAN SARAN}

\section{Kesimpulan}

a. Disiplin dan komunikasi berpengaruh positif dan signifikan terhadap kinerja dosen pada STIE Sultan Agung Pematangsiantar. Hal ini dapat dilihat dari hasil pengujian regresi yang menunjukkan tanda positif pada persamaan sebagai berikut: $\mathbf{Y}=\mathbf{1 0 , 5 3 9}+\mathbf{0 , 3 9 7 \mathbf { X } _ { 1 } +}$ $\mathbf{0 , 4 5 3 X _ { 2 }}$

b. Secara parsial (uji t), disiplin dan komunikasi berpengaruh secara signifikan terhadap kinerja dosen STIE Sultan Agung Pematangsiantar. Artinya semakin baik disiplin maka kinerja dosen akan semakin tinggi, semakin baik komunikasi maka kinerja dosen juga akan meningkat.

c. Secara simultan atau bersamaan menunjukkan disiplin dan komunikasi berpengaruh terhadap kinerja dosen STIE Sultan Agung Pematangsiantar. Artinya jika disiplin dan komunikasi secara bersamaan meningkat maka kinerja dosen juga akan meningkat.

d. Diantara kedua variabel yang diteliti, variabel disiplin berpengaruh paling tinggi atau dominan berpengaruh terhadap kinerja dosen STIE Sultan Agung.

e. Hasil analisa pada analisis regresi variabel moderasi dengan metode selisih mutlak menunjukkan tabel uji signifikansi parameter individual bahwa pada taraf signifikansi 5\%, diketahui disiplin berpengaruh positif, tapi tidak signifikan terhadap kinerja dosen. Berdasarkan output coefficient, disimpulkan pada taraf signifikansi 5\%, komunikasi berpengaruh positif dan signifikan terhadap kinerja dosen. Variabel kepemimpinan memberikan nilai koefisien 2,189 dengan probabilitas 0,04 yang artinya bahwa kepemimpinan berpengaruh positif dan signifikan terhadap kinerja dosen.

f. Pada Tabel Anova atau $F$ test menunjukkan bahwa nilai $F$ hitung sebesar 19,048 dengan tingkat signifikansi 0,000 jauh dibawah 0,05. Hal ini berarti bahwa variabel standardized disiplin, standardized komunikasi, standardized kepemimpinan dan $\mathrm{ABSX}_{1} \mathrm{X}_{3}, \mathrm{ABSX}_{2} \mathrm{X}_{3}$ secara bersama-sama atau simultan mempengaruhi kinerja dosen.

g. Dari hasil analisis menunjukkan bahwa $\operatorname{Abs}_{1} \mathrm{X}_{3}$ signifikan (probabilitas 0,46) tetapi $\mathrm{Abs}_{2} \mathrm{X}_{3}$, ternyata tidak signifikan yaitu dengan probabilitas signifikan sebesar 0,91 atau dapat dikatakan bahwa variabel kepemimpinan mampu memoderasi variabel kedisiplinan namun tidak memoderasi variabel komunikasi.

\section{Saran}

a. Untuk pihak STIE Sultan Agung

1) Variabel-variabel bebas disiplin, komunikasi dan kepemimpinan berpengaruh signifikan terhadap kinerja dosen. Untuk itu pihak STIE Sultan Agung perlu untuk memerhatikan kedisiplinan para dosen-dosennya, menjalin komunikasi yang baik dan meningkatkan kemampuan kepemimpinan agar mampu meningkatkan kinerja para dosennya.

2) STIE Sultan Agung selain memperhatikan faktor disiplin, komunikasi dan kepemimpinan juga perlu memerhatikan faktor-faktor lain yang mampu meningkatkan kinerja para dosennya juga seperti budaya organisasi, 
sistem kompensasi, fasilitas, dan faktor-faktor lainnya.

b. Untuk peneliti berikutnya, sebaiknya melakukan penelitian yang berhubungan dengan kinerja dosen dengan memperhatikan faktor lain seperti budaya organisasi, sistem kompensasi, fasilitas, pelatihan, dan faktor lainnya yang tidak dimasukkan dalam penelitian ini.

\section{E. DAFTAR PUSTAKA}

Dessler, Gary, 2006, Manajemen Sumber Daya Manusia, Jakarta: Prenhallindo.

Griffin, Ricky W, 2002, Manajemen, Jilid 1, Edisi 7, Jakarta: PT. Gelora Aksara Pratama.

.., Ricky W, 2002, Manajemen, Jilid 2, Edisi 7, Jakarta: PT. Gelora Aksara Pratama.

Mangkunegara, P. Anwar, 2001, Manajemen Sumber

Daya Perusahaan, Bandung: Remaja Rosdakarya.

Mondy, R. Wayne, 2008, Manajemen Sumber Daya Manusia, Jilid I, Edisi 10， Jakarta: Penerbit Erlangga.
Rivai, Veithzal, 2004, Manajemen Sumber Daya Manusia Untuk Perusahaan, Jakarta : PT. Raja Grafindo Persada.

Robbins, Stephen P. dan Judge, Timothy A., 2009, Perilaku Organisasi, Buku 2, Edisi 12, Jakarta : Salemba Empat.

Siagian, Sondang P, 2003, Manajemen Sumber Daya Manusia, Cetakan Kesepuluh, Jakarta : Bumi Aksara.

Simamora, Henry, 2004, Manajemen Sumber Daya Manusia, Edisi Ketiga, Jakarta: STIE YKPN.

Siswanto, Bedjo. 2005. Pengantar Manajemen, Jakarta : Bumi Aksara.

Tulus, Tu'u, 2004, Peran Disiplin Pada Perilaku Dan Prestasi Siswa, Jakarta: PT. Grasindo. http://te.unib.ac.id/download/140-permendikbudnomor-154-tahun-2014-tentang-rumpun-ilmupengetahuan-dan-teknologi-serta-gelarlulusan-perguruan-tinggi 